\title{
Vintage Design Furniture in Albania, a New Retro Design Paradigm in the Post-Communist
}

\section{Erida Curraj}

$\mathrm{PhD}$, International programme in Architecture and Urban Planning.

Ferrara University, Italy and Polis University, Albania

\begin{abstract}
The dynamics of the Albanian market in lieu of the multifaceted transformations following the collapse of the communist regime and moving towards the accession processes in the European Union as well as the demographics of the Albanian society as a whole, deeply impact the ways in which furniture products are designed, development and produced. This paper draws from my doctoral study which explored the transformation of furniture products from communism to post-communism. The doctoral study confirmed that: the impact of moving from mass production in a centralized economy to free mass customization in market economy has not radically transformed the fundamental properties of furniture but has affected the design, development, delivery and materiality of products. In this light, this paper will zoom into the furniture designs during post communism in Albania by exploring two principle paradigms vintage and retro. First this paper argues that furniture design and production in the centralized economy, are introduced within the vintage paradigm in post-communist. The data collecting through observation demonstrate a high level of interest for the retro design in a free market economy. As the result the paper suggest the local actors, businesses and academia to use and persist nostalgia and retro design in furniture and their component.
\end{abstract}

Keywords: vintage design, retro design, communist, post-communist.

\section{Introduction}

This article explores the role of furniture produce during the centralized economy in Albania, towards a path of shifting from vintage design to retro design. The role of retailers and local enterprises in making the value of retro style of these model is significant and prompt.

The design of furniture during the communism time in the Eastern Bloc has taken the attention during the last decades. Different project has be reveal and the red tourism has been more populated. The scope of this article is to find out the status of the design of the furniture produced during a centralize economy, and to propose them to the entrepreneur to proliferate design adequate in Albanian, new context of free market economy. Due to their continued popularity in other exEastern Bloc countries, the question why they aren't the same popular in Albanian market is analyzed. Newer row material has come and new assembled technology has been offer, the question is why is so difficult that Albania furniture industry, can't reach the region production scale, for these design?

This article is solely about furniture that are produce during the communism era, that exhibits characteristics of minimalism design and production system, in minimalism ,aesthetic, pure shape and mass production. The discussion focuses exclusively to the analyzing the place these furniture and ornaments take in Albanian design context and to call the manufactures to reproduce them. 
The paper start with a theoretical frame work of the definitions on "vintage" and "retro", followed by a brief introduction on the design and furniture production during communism towards communism in Albania. The third part, thought collected data from the visit on site, interviews methodology, analyze the approach of vintage communist heritage currently in Albanian interiors. The last part is analyzing the lack of developing the communist design of furniture produced during the centralized economy in Albania.

\section{Vintage vs Retro discussions continue...}

The semantic attempt looking for the definitions and distinguishing terms "vintage" and "retro" for the furniture produced during the central planning economy time in Albania market, is limited prior research from scholars.

The term "vintage" represents an attempt to claim originality for genuinely old objects (household and clothes). The M.W's dictionary [Merriam Webster online dictionary] explains that the term "vintage" used to describe something that is not new but that is valued because of its good condition, attractive design, etc. In origin, the term "vintage" refers to "wine age", the specific year and place of origin used to describe a wine usually of high quality, such as with "Bordeaux wine of a 1965 vintage". It tends to be preferred in the United States, as a term that has undergone a shift in meaning when it was applied first to clothing. The emergence of vintage and retro style have been focused on previous studies in the United Kingdom, 1960s London (e.g. Samuel 19942; Gregson \& Crewe 20033; Baker 20134). The vintage style can be attributed to particular meanings; Delong, Heinemann, and Reiley, $(2006)^{5}$ found that the vintage consumers want originality as a way to express individuality or some degree of standing out from the crowd. In addition, Cervellon, Carey and Harms (2011: 968) studied that vintage is a desire for originality, nostalgic expression, in comparison to consumers who purchase contemporary second-hand clothing and household objects.

The term "retro", attributed to reproductions - as well is used to distinguish the difference from contemporary secondhand objects- explained by M.W6. Dictionary as; looking like or relating to styles or fashions from the past. Gregson \& Crewe $(2003)^{7}$, constitutes retro in any meaningful way is not just an impossibility but a misplaced endeavor. Other connotation took the discussion "retro" in Britain when the Guardian Weekend magazine published on 26 May 2007, a special retro issue consisting of articles about authentic retro fashion, food, cars, gardens and homes. The magazine featured enthusiasts in interiors section, where living rooms surrounded by their retro objects from various decades including 1950s fabrics until 1970s patterned wallpaper. Particular items of furniture and decorative objects in Britain, that previously considered old-fashioned and everyday, illustrate the proliferation of the term 'retro' to describe the increase in the value of items. The term was adopted in Britain and a shop bearing the name 'retro' appeared in London in 1974 (Samuel, 19948).

In the early 1970s, in France, occur the use of the word "retro" to describe material and cultural products objects. It emerged as a persisted way to indicate the growing interest in styles from the recent past in French avant-garde cinema, at Parisian fashion houses and at street markets (Guffey, 20069; Samuel, 1994). The American Retro store, sold original and newly manufactured items in styles from the recent past, and retro continues to be used to describe both these activities (Dunkley, $2005)^{10}$.

The retro retailers are conceptualizing objects and styles both in appropriate symbolic (cultural) and materiality, through buying and selling goods. They change the value of items from every day and old-fashioned to unique and desirable through knowledge and practices. In this process of value creation, retailers mediate between production and consumption and

\footnotetext{
1 Merriam Webster online dictionary

2 Samuel R (1994) Theatres of Memory. Volume 1: Past and Present in Contemporary Culture. London: Verso.

${ }^{3}$ Gregson, N. and Crewe, L. (2003) Second Hand Cultures. Berg: Oxford

${ }^{4}$ Baker, Sarah Elsie (2013): Retro Style: Class, Gender and Design in the Home, New York: Bloomsbury

5 DeLong, Marilyn, Barbara Heineman and Kathryn Reiley. 2005. "Hooked on Vintage!" Fashion Theory 9(1): $23-42$.

${ }^{6}$ ibrid

7 ibrid

8 ibrid.

${ }^{9}$ Guffey E (2006) Retro: The Culture of Revival. London: Reaktion.

10 Dunkley C (2005) Essential Guide to London's Retro Shops. London: New Holland Publishers.
} 
translate and evaluate other cultures. As such, their role fits well with past theorisations of cultural intermediaries (Baker, S.E. 2012) $)^{1}$.

Pile (2005: 231)2 states at the book A History of Interior Design that since the Renaissance, there has been an interest in learning from the past and in borrowing elements to be used in a new context. The revivaling of these elements can be attributed due to different resons; Beverly Lemire (1988) suggests that consumption in the early industrial period was 'twotiered'. The upper classes had enough wealth to buy the decorative objects and furniture that they desired, but the rest of the population were able to afford only second-hand goods purchased from junk shops, and flea markets. By the 19th century, due to industrial production offered cheaper goods to larger proportions of the population, the size of this trade had decreased dramatically. Enabling the widespread manufacture of reproduction furniture and decorative objects.

The sale of second-hand and reproduction objects has been a feature of street markets and continuing to find in the market called "old/black market" often in the biggest cities, in Albania as well. Many of the used furniture, ornaments, clothes are sent in these market where you can find goods dated since years1930's, a good part from communism era and some "once upon a time towards Europe" goods. The third group is rich in origin made in quality and designs. The second group products produce during the communism time, take my attention when I visit these markets. As the generation born during the last decades of Albanian communism, I was witness of; the simplicity interior, modest fabric, pure lines and designs reflecting the peaceful design, reminding childhood sweetness feeling I can fairly call them a humble design. Eventually these products has capture the attention of the Albanian designer, approaching the interiors of bars and restaurant in similarity of the residential interiors during the communist time in Albania, but for sure enriched in quantity and fashion in current context.

In this sense, the furniture produced during the communist time in Albania, which aren't new, still in good conditions, attractive design, they are valuated from the retailers, or second hand shop and designers, expressing the Albanian individuality, originality of communism interiors can be truly called "vintage" furniture and ornaments.

The discussion opened between architects, one afternoon drinking in a bar designed as above, lighted my motivation to study deeper the distinguishing between these two terms and as far as these products are embraced from client why we don't have a reproduction of these furniture in Albanian market? There has been asked 18 people if we can call these interiors furnished with "retro" or "vintage" furniture designs, 12 of 18 people answered "retro" Associated with return design. Referring to the definition above 'retro' is used to describe the revival of past styles, defining the mass production in today post-communism time, of the vintage design produced during the communism time.

\section{Designs Produced from Communism to Post-Communism in Albania}

The furniture design during communism can be characterized as mass production strongly impacted by the political dogma of the time (Curraj,E. 20173). The two main features of this mass production were: Standardization of home furniture design process and product development and rationalism, which referred to the quantity of products one household could actually own. The political dogma limited the mass consumption of products regulated by supply - demand balances, which are common in free, market economy. The communism regime was controlling not only the production but also the way of living and thinking; this was also mirrored on furniture design. The centralizing of the design process as a whole, and with regard to furniture in particular, was heavily influenced by the ideology of the communist regime and served as a means of propaganda, signaling power of the ruler and the state that were to be feared and respected (Sudjic, 2005).

\footnotetext{
1 Sarah Elsie Baker(2012), Retailing retro: Class, cultural capital and the material practices of the (re)valuation of style, European Journal of Cultural Studies 15(5) pg 621-641

2 Pile JF (2005) A History of Interior Design. London: Laurence King Publishing

${ }^{3}$ Curraj,E. (2017). Reinventing Furniture Design in the post-communist Era in Albania: towards the Mass costumization Paradigm. PhD desgree's dissertation.Ferrara, Italy

${ }^{4}$ Sudjic, D. (2005) The edifice complex. New York: The Penguin Press. The Economist "Mass customatisation", The Economists, available at http://www.economist.com /node/14299807
} 
The furniture industry in Albania, one of the most important craft industries in the country, dates back to before XIV century, when artisans created traditional motive's ornaments and furniture (1985)1. During years 1930's furniture manufacturing production, a limited amount of investment has been done on new technology but a small quatity covered the Albanian demands, the producers were export oriented. The wood processing industry became highly developed in communism and from the first wood processing plan in Puka in 1945 and Misto Mame in 1952, many more were set up in at least 23 cities which had proximity to raw materials, namely wood. The wood processing used standardization procedures, high technology for the time and many of the products were exported particularly in the 1970s and 1980s. The encompassing features either for export or local use of products was the high quality of products and materiality used.

But increasing of the imported furniture was as well due to the lack of furniture manufactures, after 90 's the industry was demolished, destroyed "as part of communism rudimentary retribution" no production, no technician, no interior professions. Retailers of consumer products where interested to sell the importing products. After Albania emerged from 50 years of communist rule, the transition from a centrally planned to a market-oriented economy, together with substantial international aid and other strategic assistance from the European Union, World Bank, USA and other countries helped the country make progress. As such Albania grew from the poorest nation in Europe in the early 1990 s to middle-income status in 2008 , with poverty declining by half during that period.

On Phd research (Curraj,E 2017) ${ }^{2}$ the observation and interviews, showed that despite the economic reason, was not the only factor that after the fall of communism the interiors in Albania lost their design identity, but as well in their a communism rudimentary retribution, a rhetoric of revenge against any element that could at least induce the communist element. This was a phenomenon spread in every field of the life, stile life, and clothes. The interior during the transition time from communism to post-communism identified as a Hybrid interior, where the existing furniture and the wood hand crafting furniture where mixed with the new imported one. Indeed the hybridity, shaped Albanian interiors from the beginning 1990s discussion on the interior changed from promoting adherence to one particular style and decorating in this way, to an eclecticism that encompass many different styles in one room.

After 10 years struggles small wood enterprises developed in rural area close to main cities, their designs were imported from abroad, or they bought in the local area from the biggest furniture retailers. This copy products were under no quality control and on demands qty. Non-formal areas of furniture production, were spending no penny for developing the design, taking care of marketing just for the distribution where often their packing way were not on the proper quality. Small wood workshop were developed near/in the habitable areas, they were produced global spare parts and wooden row material, the architect's role was more welcomed than the previous years. The customs were more pleased about the quality control but the delivery time was more delicate to produce products on demands.

As mostly of the ex-communist country Albania run to catch the global trend, the market welcome the phenomenon of shopping malls, a place where people can buy grocery, accessories, clothes in different options and in different quality, price. The consumption power increased and buyers' awareness on quality and designs.

\section{Vintage design in Albania in post communism paradigm.}

The dynamics of the Albanian market occurrence of; first, the multifaceted transformations following the collapse of the communist regime, second, moving towards the accession processes in the European Union, third, the demographics of the Albanian society as a whole, deeply impact the ways in which products are designed, development and produced. With the free market economy, first, the role of the state was diminished significantly and the Albanian society embraced the mass consumption cultural trends. Secondly, the levels of migration and emigration raised significantly which resulted in the need for new products for home furniture and decoration. In this sense, the path of transformations of the Albanian customer with the market economy.

During these transformations (social, cultural and economic changes), when the social aspect of architecture and home furnishing became important in a particular market the basis of the design of furniture had to be changed. Furniture during

\footnotetext{
${ }^{1}$ Akademia e Shkencave RPSH (1985). Fjalori Enciklopedik Shqiptare. Shtypur Kombinati Poligrafik shtypshkronja e Re,Tirane

${ }^{2}$ Curraj,E. (2017). Reinventing Furniture Design in the post-communist Era in Albania: towards the Mass costumization Paradigm. PhD desgree's dissertation.Ferrara, Italy
} 
socialist era, produced at minimal cost, with practical considerations dominant throughout, Albania, other Easter Balkan country, may be held to be less fully aesthetic, than those on which the designer has more freedom of choice in the use of materials and the distribution of the parts. Homes became smaller and the economic factor began to play a more important role than heretofore.....in her article Sarah Reeder, ISA is the owner of Artifactual History Appraisal, states: The demand for furniture for show was, therefore, superseded by an urgent call for practical furniture in a reasonable price-range, and at the same time the predilection for furniture in suites was replaced by a preference for individual pieces which made possible a freer and more personal style of furnishing." ${ }^{1}$ Practical, aesthetic, and economic considerations are all involved, and the quality of the individual article is dependent on a nice balance of all three.

Vintage design is is intertwined with the human factors such as emotional and cognitive. In this sense there are sceptic to embrace this interior in the residential houses and some others discuss that this design is more similar to modern designs that what everybody has in their mind "Vintage". But this direction is sending to the other context as Christopher Wilk 2 defines modernism, in the introduction to the book Modernism 1914-1939: Designing a New World, in the context of design an equally vociferous rejection of history and tradition; ...its principles were frequently combined with social and political beliefs (largely left-leaning) that held that design and art could, and should, transform society. However, if in Britain in the mid-1960s a different way of producing and consuming the past emerged, in Albania this is eventually started especially after 2010's. The spread places where could be found this goods that predated 1990 are bazaars, open market, salerooms, auction houses (very few). Secondhand furniture retails, sold odd pieces, were relatively new in "vintage" terms, when during the transition time viewed as junk.

Vintage of the communist products in Albania is the proliferation of the vintage style of the products produced during communism, which has become widespread in entertainment and accommodation facilities such as hotels, bars and stores.

\section{Shifting from vintage to retro}

Last years, in Albania, the number of bars and restaurants as well as hotels is increasing, more and more furnish with the style of 'communist heritage'. However, attention should be paid here to the interpretation of heritage of communism. The idea is not to transform communism into a positive image and thus increase nostalgic dimension, but to focus on the architectural and cultural heritage that emphasize a variety of interpretations of communism heritage in Albania. If the region countries as; Montenegro, Macedonia, Serbia. Bosnia, Bulgaria Croatia, are evaluating this heritage and exporting in considerable quantity the question being raise is; why Albania isn't running in the same speed with the region countries on reviving of goods produced during communism.

Study made on comparison of the wood industry with the focus on the furniture production and design process (eg, NIBA 19973; Çaushi, Marku, and Lato. $2015^{4}$ Glavonjic, 20085), analyze the potential of the furniture production with the focus of the design produce during the communist period. As the member of the Eastern Bloc, the design of furniture led from the same principle. All the above countries are very sensible in producing heritage design and their export is significant. The furniture manufactures are currently in a state of upsurge and its significance for these countries economy.

Unfavorable conditions of the present state why this heritage of designs produced during the centralized economy are:

-Omission of inheritance, losing Albanian's design identity

The original contribution of the Curraj, E. (2017) dissertation on PhD degree In Architecture, is the thorough analysis of the furniture design process and products during the communism period in Albania. The findings are entirely based on collection of primary data through systemic review of archiving and document analysis, in-depth interviews and observations. This doctoral study, for the first time in Albanian scholars is cataloging the design of furniture produce during the communist time in Albania. Thus presents a comprehensive picture not only of furniture design process and products but also of

\footnotetext{
${ }^{1}$ Reeder, S. An Introduction to Appraising Mid-Century Modern Furniture. International Society of Appraisers.

2 Christopher Wilk. "Introduction: What was Modernism?" in Modernism 1914-1939: Designing a New World (South Kensington: V\&A

Publications, 2006), 14.

${ }^{3}$ NIBA consult Ltd. (1997). Survey on the Industry of furniture in Bulgaria

${ }^{4}$ Çaushi, Marku, Lato (2015): Devolopment of wood processing and furniture manufacturing sector in Albania and the western Balkans.

International Journal - Wood, Design \& Technology, Vol.4, No.1, (2015):9-20

${ }^{5}$ Glavonjic, B. and R. P. Vlosky, (2008): Timber-sale systems in the Balkan region. J. Forestry 106(4):206-213.
} 
interrelated dimensions such as house layout, social-economic and political contexts that led to certain types of product design during this period.

-a rhetoric of revenge, be against and don't let space of reflection

Albania furniture design produced during centrally-planed characterized by uniformity, centrally planned design, not possibility of choosing quality, price, or design. This obligated uniformity dispersed immediately after the fall of communism after 90's. Still, currently there are quite alot people skeptics on approaching and welcoming this design. One of the limitation of the (above) research on design produced in Communist time in Albania is resistance on accepting this design.

-fall of communism, fall of furniture manufacturing

There was no other cases in region, as Albania was, destroying all the communism wealthy, industries, cutting forest, emigrating. The first 10 years of post-communism, the industry was weak, in the lowest remuneration category. Total decentralization led to a multitude of problems for the furniture manufacturing industry, characterized mainly by a lack of information and market research, accumulation of inventory, and dependence on bank loans. The high skill professional workers, decreased due to the emigration. Albania started to run towards globalization and development of wood industry, but with a delay of 10 years comparing with the region's country.

Albania has many favorable to catch promptly the region, production of the design heritage from years 1950' to 1990 .

- Albanian National Psychology. Albanian's cherish possessing and furnishing their homes with care and taste. Modern trends for current and complete house redecoration have also found their way here.

- The Albanian's Industrial Capacity. The socialist period witnessed the construction of impressive furniture manufacturing center spread throughout the country. This is a good base for a profitable industry

- Well Developed Infrastructure. Large furniture factories are connected by road.

- Availability of Raw Materials. Albania has enough wood to satisfy the needs of furniture production. Today, unfortunately, still importing is the higher level than exporting in the industry of wood and manufacturing.

- Well Qualified Workforce. Albania has specialized schools and institutes, highly qualified furniture production and design specialists.

- Connection with Priority Branches. The development of tourism in Bulgaria is closely connected to the complete and modern furnishing of tourist outlets, which significantly expands the home market. for a profitable industry

Considering that Albania has been very isolated (self-isolated) during communism and also considering that in the past 20 years, western tourists have started to be interested in the heritage of the communist period, in seeing what it was like to live behind the Iron Curtain, the communism heritage tourism could be profitable for small businesses in Albania.

\section{Conclusion}

The design of the products produce during a centrally-planed economy of Albania , are conceptualized and produced based on the same principals of design as other ex- Eastern Block counties.

The term "vintage" used to describe something that is not new but that is valued because of its good condition, attractive design, in this sense the designs of furniture and ornaments produce during communism time could be called "vintage". Vintage of the communist products in Albania is the proliferation of the vintage style of the products produced during communism, which has become widespread in entertainment and accommodation facilities such as hotels, bars and stores.

Thee number of bars and restaurants as well as hotels is increasing, more and more furnish with the style of 'communist heritage'. However, attention should be paid here to the interpretation of heritage of communism. The idea is not to transform communism into a positive image and thus increase nostalgic dimension, but to focus on the architectural and cultural heritage that emphasize a variety of interpretations of communism heritage in Albania.

In Albania is a lack of collaboration between main actors, academia, enterprises and government that can emphasize the project of communist heritage of furniture design. As the member of the Eastern Bloc, Albania could be very sensible in producing heritage design and their export could be significant, as the other region's counties. 
With this article despite the analyzing of the design's status of products produced during the centralized economy. As well is a call for approaching actors between each other is more significant and emergent. Albania furniture manufacturing need to find its identity, helped from the scholars research, and to implement on the right paths.

Reproduction of household during the post communist era, of the design of household designed and produced during communism time is attribute as" retro" design.

This paper wants to reach mass production, reproductions of household produced during centralized economy in Albania, produced as part of many historic revivals, is becoming increasingly available to wider sections of the entertainment spaces. This is the moment where manufacturers and retailers interpreted the styles, designs and patterns available as part of revivals, and offered 'enormous choice for their customers by producing their own versions as well as supplying reproductions of actual historical models, some more accurate than others' (Francis Collard , 2003: 48)'.

\section{References}

[1] Akademia e Shkencave RPSH (1985). Fjalori Enciklopedik Shqiptare. Shtypur Kombinati Poligrafik shtypshkronja e Re,Tirane

[2] Baker, Sarah Elsie (2013): Retro Style: Class, Gender and Design in the Home, New York: Bloomsbury

[3] Çaushi, Marku, Lato. (2015): Development of wood processing and furniture manufacturing sector in Albania and the western Balkans. International Journal - Wood, Design \& Technology, Vol.4, No.1, (2015):9-20

[4] Christopher Wilk. (2006) "Introduction: What was Modernism?" in Modernism 1914-1939: Designing a New World (South Kensington: V\&A Publications, 2006), 14.

[5] Collard, F (2003) Historical Revivals, Commercial Enterprise and Public Confusion: Negitiating Taste, 18601890. Journal of Design History, Volume 16, Issue 1, 1 January 2003, Pages 35-48

[6] Curraj,E. (2017). Reinventing Furniture Design in the post-communist Era in Albania: towards the Mass customization Paradigm. PhD degree's dissertation. Ferrara, Italy

[7] DeLong, Marilyn, Barbara Heineman and Kathryn Reiley. 2005. "Hooked on Vintage!" Fashion Theory 9(1): 2342.

[8] Dunkley C (2005) Essential Guide to London's Retro Shops. London: New Ho

[9] Glavonjic, B. and R. P. Vlosky, (2008): Timber-sale systems in the Balkan region. J. Forestry 106(4):206-213.

[10] Gregson, N. and Crewe, L. (2003) Second Hand Cultures. Berg: Oxford

[11] Guffey E (2006) Retro: The Culture of Revival. London: Reaktion.

[12] Merriam Webster online dictionary

[13] NIBA consult Ltd. (1997). Survey on the Industry of furniture in Bulgaria

[14] Reeder, S. An Introduction to Appraising Mid-Century Modern Furniture. International Society of Appraisers.

[15] Samuel R (1994) Theatres of Memory. Volume 1: Past and Present in Contemporary Culture. London: Verso.

[16] Sudjic, D. (2005) The edifice complex. New York: The Penguin Press. The Economist "Mass customatisation", The Economists, available at http://www.economist.com /node/14299807

1 Collard ,F ( 2003) Historical Revivals, Commercial Enterprise and Public Confusion: Negitiating Taste, 1860-1890. Journal of Design History, Volume 16, Issue 1, 1 January 2003, Pages 35-48 